\title{
HTLV-I Associated Myelopathy: An Endemic Disease of Canadian Aboriginals of the Northwest Pacific Coast?
}

\author{
Joël J.F. Oger, Denise H. Werker, Dean J. Foti and Gregory A. Dekaban
}

\begin{abstract}
Human T-cell lymphotropic virus type 1 (HTLV-I) is responsible for HTLV-I associated myelopathy or tropical spastic paraparesis (HAM/TSP) and for adult T-cell leukemia/lymphoma (ATLL). Both diseases have been well described in individuals living in Japan, West Indies, Seychelles Islands and Columbia where infection with HTLV-I is considered endemic and in persons whose descendants originated from these endemic areas. We report here 4 cases of HAM/TSP in 4 natives from 4 different tribal groups from British Columbia (B.C.). These are the first case reports of HTLV-I linked diseases found among North American Aboriginals. Possible routes of infection for HTLV-I infection included sexual transmission, breast feeding, blood transfusions and IV drug use. The seroprevalence of HTLV-I in North American Native population is unknown and we suggest that it is endemic in this ethnic group.
\end{abstract}

RÉSUMÉ: Myélopathie associée à HTLV-I: une maladie endémique chez les amérindiens du nord-ouest de la côte du pacifique. Le virus HTLV-I est responsable d'un type de myélite chronique appelée myélite associée à HTLV-I ou paraplégie spastique tropicale (HAM/TSP) et de la leucémie à lymphocytes T de l'adulte (ATLL). Ces deux maladies sont bien connues chez les habitants de régions endémiques telles que les Antilles, les Seychelles, le Japon et la Colombie. Nous décrivons ici 4 cas de HAM/TSP chez des Amérindiens appartenant à 4 tribus différentes de la Colombie Britannique. Ces cas de maladies liées au virus HTLV-I sont les premiers à être rapportés chez les indiens d'Amérique du Nord. Dans les cas que nous avons relevés nous suspectons que le virus a été transmis par les rapports sexuels, le lait maternel, la transfusion sanguine et l'usage de drogues par voie IV. La prévalence de la séropositivité chez les Amérindiens n'est pas établie mais nous suggérons que dans ce groupe ethnique l'infection par HTLV-I pourrait être endémique.

Can.J. Neurol. Sci. 1993; 20:302-306

Originally described as Tropical spastic paraparesis (TSP), the myelopathy associated with HTLV-I infection is now referred to as HTLV-I associated myelopathy/Tropical spastic paraparesis (HAM/TSP).' HAM/TSP is an inflammatory and demyelinating myelopathy with a chronic progressive evolution over a number of years. It has been reported in Japan, ${ }^{2}$ both in French ${ }^{3}$ and English West Indies, ${ }^{4}$ Columbia, the Seychelles and Southern U.S. ${ }^{5}$ The cases previously recognized in Canada have been among immigrants from the West Indies except for one patient who immigrated from Chile. ${ }^{6}$ We have now identified 4 Aboriginals with HAM/TSP and one with Adult T Cell Leukemia/ Lymphoma (ATLL). We suggest that HTLV-I infection is endemic in the Aboriginal population of Western Canada.

\section{Case Reports}

\section{Patient I (HAM)}

A 59-year-old Native woman from the Bella-Bella tribe married into the Owekino band on the West Coast of British Columbia. In July 1990 (age 58) she developed band like pain across the abdomen and the back. She began to drag her left leg in the Fall 1990 and by June 1991 she was paraparetic with urinary retention. In July 1992 she was confined to bed with severe weakness in both lower extremities. Cranial nerve examination and motor examination of the upper extremities were normal. There was marked loss of muscle bulk in both legs despite clonus, hyperactive tendon reflexes and bilateral Babinski signs. Touch, pinprick and temperature sensation were mildly diminished from T6 to T1I and on the right leg. Vibration and proprioception were reduced in both legs. Somato sensory evoked potentials (SSEP) were abnormal in both legs and arms. Visual evoked potentials were normal. Magnetic resonance imaging (MRI) of the head and of the spinal cord was normal. EMG showed marked denervation in both lower legs. CSF was inflammatory with increased cells, proteins, IgG and oligoclonal bands (see Table 1). Serology for HTLV-I/ll was positive by ELISA and Western blot on both CSF and serum. Specificity for HTLV-I was confirmed with synthetic peptide ELISA kits from Olympia and Biochem Immunosystems. ${ }^{7}$ An HTLV-I specific polymerase chain reaction (PCR) was positive on DNA obtained from blood lymphocytes. HTLV-II was not detected by HTLV-II specific peptide ELISA and by PCR. She transiently improved with IV Methylprednisolone and a brief course of p.o. Prednisone. In February 1993 she died of septic shock (no autopsy was performed).

From the Division of Neurology, Department of Medicine,University of British Columbia, Vancouver, (J.J.F.O., D.J.F.); Department of Health Care and Epidemiology, University of British Columbia, Vancouver, (D.H.W.); Immunology Group, John P. Robarts Research Institute, London, (G.A.D.) Received May 13, 1993. Accepted August 11, 1993

Reprint requests to: Dr. Joël Oger, University Hospital (UBC site), 2211 Wesbrook Mall, Vancouver, British Columbia V6T 2B5 
Risk factors for HTLV-I infection included 3 blood transfusions in 1954, 1958 and 1962. She denied I.V. drug abuse and multiple sexual partners. Her husband's serum was weakly positive for HTLV-I antibodies by ELISA and Western blot but HTLV-I DNA was successfully identified by PCR from DNA lymphocytes isolated from blood. The 2 sons tested (out of 4 children) were negative.

\section{Patient 2 (HAM)}

A 44-year-old Native woman of the Squamish band, she is considered a status indian despite the fact that both paternal and maternal grandfathers came from Chile. She reported progressive weakness and stiffness in her legs over 1 year as well as minor bladder dysfunction. In December 1992 cranial nerves and upper limbs were normal. In her legs there was mild distal weakness bilaterally affecting tibialis anterior, flexor and extensors of the toes as well as peronei muscles. Tendon reflexes were increased with clonus at the left ankle and there was bilateral extensor plantar responses.

CSF was inflammatory (see Table 1). MRI of the spinal cord was normal. MRI of the head revealed a few areas of high signal intensity in the white matter of the right frontal lobe on T2-weighted images. Serology for HTLV-I/II was positive by ELISA and Western Blot. The differential peptide ELISA was positive for HTLV-I and not for HTLVII. PCR rescued specifically amplified HTLV-I DNA from DNA obtained from blood lymphocytes. HTLV-II was not detected by HTLVII specific peptide ELISA and PCR. She temporarily improved with Methylprednisolone and Prednisone.

Risk factors: She has had multiple sexual partners ( 6 to 8 different partners/year from 1980-1990). She denied drug abuse and did not receive blood transfusions. Her husband was also positive for $\mathrm{HTLV}-\mathrm{I} / \mathrm{Il}$ antibodies by Western blot analysis. His HTLV-I carrier state has been confirmed by PCR on DNA isolated from blood lymphocytes. His neurological examination and his blood smear were normal. He received some blood transfusions in Germany in the 1950's while in the U.S. military.

\section{Patient 3 (HAM)}

A 43-year-old woman from the Nutkak tribe (Mowachaht band) on Northern Vancouver Island with a history of a very progressive spastic paraparesis since 1967 when she was 17. She had been diagnosed with MS at age 20. She began to use a cane in 1979 and has been wheelchair bound with urinary incontinence since 1985 . The disease had remained stable over the last 8 years. On examination in January 1993 she was confined to bed due to weakness. Her cognition was normal but she had abnormal eye movements consisting of broken pursuit with saccadic intrusions, downbeat nystagmus on down gaze and horizontal nystagmus in lateral gaze. Fundi and visual acuity were normal. Motor examination was normal in upper extremities but there was severe spasticity in both legs with marked weakness. Reflexes were hyperactive with bilateral ankle clonus and extensor plantar responses. There were no sensory abnormalities. She was found to have chronic urinary retention.

VER were prolonged bilaterally and SSEP from the R lower extremity were abnormal. CSF showed minimal inflammatory changes (see Table 1). MRI of the head showed at least 3 distinct area of increased signal in the white matter. MRI of the cord showed mild narrowing in the thoracic region. CSF and serum were positive for HTLV-I/II antibodies by ELISA and Western blot. HTLV-I Specific Western blot analysis with Gp 46 was positive. Specific amplification by PCR on DNA obtained from blood lymphocytes rescued HTLV-I sequences and no HTLV-II.

Table 1. CSF Results

\begin{tabular}{|c|c|c|c|c|}
\hline & Cells $^{1}$ & Proteins $^{2}$ & $\operatorname{IgG}^{3}$ & $\mathrm{OCB}^{4}$ \\
\hline Patient \#1 & 13 & 900 & 109 & present \\
\hline Patient \#2 & 59 & 1080 & ND & ND \\
\hline Patient \#3 & 8 & 450 & 76 & absent \\
\hline Patient \#4 & 11 & 660 & 58 & present \\
\hline
\end{tabular}

$\mathrm{ND}=$ Not done
Risk factors: The patient had been breast-fed by her mother who at the time was known to have leukemia; she died when the patient was 2 years-old and no information was available on the type of leukemia. The patient had not received any blood transfusion and denied IV drug abuse. Her first symptoms appeared prior to becoming sexually active. Two of the patient's four children (a daughter aged 20 and a son aged 7) are sero-positive and not affected. Similarly her daughter's husband is seropositive. The wife of the patient's younger brother is zero-positive as well as their 8-year-old daughter.

\section{Patient 4 (HAM)}

A 46-year-old woman of Metis origin (Manitoba) developed progressive stiffness in her legs over one year beginning in 1991. She complained of a burning sensation in her legs and chronic urinary retention began in 1992. She also had a 20 year history of seizures for which she was treated with Phenytoin. On examination mentation was slow and there was a nystagmus. There was minimal distal weakness in both lower extremities with spasticity in both upper and lower extremities. hyperactive tendon reflexes and a positive jaw jerk. There was reduced muscle bulk in both legs. Plantar responses were extensor. There was some hyperpathy in both legs distally. Coordination was normal but her gait was spastic.

CSF was inflammatory (see Table 1). VER were normal but her SSEP were slightly prolonged from the legs, normal from the arms. MRI of the brain showed two area of increased signal in the left centrum semi-ovale on T-2 weighted images: these were interpreted as non specific. MRI of the spine revealed mild cervical spondylosis with subtle flattening of the cord which was not atrophic. HTLV-I/II serology was positive on serum and CSF by ELISA. PCR on DNA from blood lymphocytes rescued HTLV-I. Her husband was seronegative at time of writing.

Risk factors: She received blood transfusion in 1988. She used IV drugs in downtown Vancouver around age 20 and had multiple sexual partners at the time.

\section{Patient 5 (ATLL)}

Drs. J.M. Connors and R. Gascoyne of the British Columbia Cancer Agency have provided us with a fifth case of HTLV-I related disease: a 43-year-old Native man from Norttern Vancouver Island died in 1988 after being diagnosed in 1987 with adult T-cell leukemia/lymphoma (ATLL). He was born in 1944 in Kincome inlet. In 1988 the patient's serum and his wife's serum were confirmed to be reactive for HTLV-I antibodies by Western Blot. Recently his wife's state was confirmed by ELISA and Western Blot. HTLV-I sequences were successfully amplified by PCR from DNA isolated from her blood lymphocytes. HTLV-II was not detected by HTLV-II specific peptide ELISA and PCR.

Risk factors: in 1968, he used IV heroine. He had many sexual partners. There was no history of blood transfusion. His wife had received several blood transfusions in 1965 and 1970.

\section{Discussion}

The presentation of a progressive myelopathy affecting essentially the lower extremities with subtle to absent sensory finding but significant bladder dysfunction is quite compatible with descriptions of HAM/TSP. ${ }^{8}$ CSF findings have confirmed the inflammatory nature of the disease in the 3 patients with recent onset (patients \#1, \#2 and \#4). The minor degree of inflammation in Patient \#3 may be attributed to the long duration of the disease ( 20 years) without progression over the past 8 years. This is in agreement with findings that in HAM/TSP inflammation tends to subside as time passes. ${ }^{9}$ Findings of positive antibodies by ELISA method may give false positive but all our cases have been verified by Western blot. ${ }^{10}$ HTLV-I DNA has been amplified by PCR from DNA obtained from blood lymphocytes in the 4 patients with myelopathy. These patients therefore fulfill the criteria for HAM/TSP. Some have suggested to isolate the virus from CSF cells to confirm the diagnosis." This would certainly lend support for a role for HTLV-I in disease pathogenesis but we are not convinced it is necessary for 
diagnosis. Reliability of current Western Blot kits and HTLV-I specific PCR make our findings sufficient for diagnosis.

In the $4 \mathrm{HAM} / \mathrm{TSP}$ patients reported here, only females were found to be affected. In contrast 3 their 4 husbands were serologically positive but not affected. Female predominance (in a 2:1 ratio) is a common finding in HAM/TSP; it has been suggested that this is an argument for the auto-immune theory of pathogenesis. ${ }^{12}$ We are surprised not to have found a single affected male. Similarly we are surprised that no other case of HTLV-I positivity among ATLL cases in B.C. has been reported. These differences from Japanese studies could be related to differences in immunogenetic background and merit further investigation.

Patients 2 and 4 have lived as street peoples similar to cases recognized in the U.S. ${ }^{13}$ by systematic testing of blood donors with IV drug abuse and multiple sexual contacts. This is quite different from patient \#3 where mother to child transmission is apparent over 3 generations with transmission from a leukemic mother by breast milk to a child who develops HAM/TSP and patient \#3 transmitted HTLV-I down to her daughter who is now a healthy carrier at age 20 .

Interestingly 2 of the 4 HAM patients (patients \#1 and \#3) had been diagnosed with MS based on the presence of a myelopathy in a young woman combined with an inflammatory CSF. Evidence of multifocal involvement in the form of a nystagmus and slowed VERs were even found in patient \#3 and a nystagmus in patient \#4. Albeit not typical of MS the findings on MRI could have supported the diagnosis of MS. Findings of a few area of demyelination by head MRI are common in HAM/TSP. ${ }^{14}$ However MS is so rare in Canadian Native Aboriginals, ${ }^{15}$ that this diagnosis was felt to be improbable and as HTLV-I is not an aetiological factor in MS, ${ }^{16}$ HTLV-I serology was requested leading to diagnosis. Dissemination in time and space is a major argument in Poser's classification of MS diagnosis ${ }^{17}$ and these 2 patients could have been diagnosed as clinically definite MS except for the fact that these authors, after Schumacher ${ }^{18}$ insist that other diagnosis be ruled out. In individuals originating from endemic areas (Japan, Caribbean Basin, Columbia and Southern U.S.) this would include HTLV-I serology. Our results suggest that HTLV-I serology should be done in Natives suspected of having MS.

Routes of infection for HTLV-I are similar to HIV: they are horizontal, by parenteral exposure through either transfusion of cellular blood products and through sharing of contaminated needles, or through sexual intercourse, as well as vertical from mother to child. Mother to child infective routes include transplacental, intrapartum or through breast feeding. The efficiency of transmission is dependent on the mode. Blood transfusion is the most efficient; seroconversion of recipients of HTLV-I contaminated blood is reported as $35-60 \%$. Based on Japanese data, seroconversion due to exposure during sexual intercourse is more efficient from male to female $(60.8 \%)$ than from female to male $\left(0.4 \%\right.$ over a 10 year period) ${ }^{19}$ Breast feeding is considered the most significant vertical route of infection with an efficiency of transmission estimated as 20 to $25 \% .{ }^{20}$ The lifetime risk of disease if infected with HTLV-I is estimated at 1 to 4 percent for ATLL and 0.1 to 1 percent for HAM/TSP. The latency period between seroconversion to expression of disease is estimated to be 20-30 years for ATLL. The latency period for HAM/TSP is generally shorter ${ }^{21}$ but cases have been recognized up to 30 years after transfusion. ${ }^{12}$ No ATLL cases have yet been linked to infection by blood transfusion. In contrast, HAM/TSP cases have shown a earlier disease onset when there is a history of blood transfusion. Patient \#1 received a blood transfusion 30 years before onset of disease. No other risk factor was found. Her husband however also was seropositive and it is unclear who was initially infected. In patient \#2 both husband and wife are seropositive. Both could have contracted the virus as they both had multiple sexual partners. Only the husband received blood transfusions 30 years before onset of his wife's disease. In patient \#3 vertical transmission is most likely over 3 generations. Patient \#4 had been an IV drug abuser and has had multiple sexual partners, she also had 1 blood transfusion. In the ATLL case (Patient \#5) risk factors were IV drug use and multiple sexual partners; as efficiency of sexual transmission is low from female to male, it is more likely that he was infected by contaminated needles during IV drug abuse and subsequently infected his wife. The latency period from infection to diagnosis of disease may have been as long as 32 years.

Corroborative evidence that HTLV-I could be endemic among Natives in B.C. has been lacking. A recent survey of Ontario hemophiliacs and HIV positive serum samples obtained from the Canadian Red Cross Donor HIV screening program, failed to identify any HTLV-I positive specimens. ${ }^{22}$ The B.C. Cancer Agency conducted a prospective HTLV-I screen on all 300 new cases of lymphomas over an 18 month period in 1989-1991. No HTLV-I positive cases were found in newly diagnosed lymphomas during that period (Drs. R. Gascoyne, BCCA, Personal communication). In Canada, the Red Cross started screening blood for HTLV-I/HTLV-II in the spring of 1990 (HIV screening began in November 1985). An ELISA positive screen is forwarded to the National Red Cross Reference Laboratory in Ottawa for Western Blot and/or radioimmune precipitation assay (RIPA). Since the initiation of screening in B.C., 42 out of approximately 350,000 donated units have been reactive ( $\mathrm{Dr} P$. Tsang, Vancouver Red Cross blood donor clinic, Personal Communication). These cases have not been pursued as no ethnical information is generated by the Red Cross on blood donors. A study of blood donors in 3 metropolitan centres in Canada, showed that approximately 80 to $85 \%$ of reactive specimens were attributable to HTLV-I infection and 15 to 20\% HTLV-II (Dr. P. Gill, Red Cross National Reference Laboratory, Ottawa, Personal communication to D.W.). This contrasts with a U.S. seroprevalence study where only $16 \%$ of seropositive samples from drug-treatment centres and $31 \%$ of those from clinics for sexually transmitted disease were due to HTLV-I infection. ${ }^{2.3}$

We have thus recognized 5 Aboriginal Natives with HTLV-I associated pathology, 4 with HAM/TSP and 1 with ATLL. We have also identified 10 further cases of seropositivity in their immediate relatives. As these 5 cases originate from different tribes living in different parts of a vast province it is quite possible that British Columbia Aboriginals are a population where HTLV-I is endemic.

The frequency of HTLV-I seropositivity among Aboriginals can be estimated by extrapolating from Japanese figures of 1 case of HAM/TSP for 1,000 infected individuals. Given 4 cases of HAM/TSP we estimate that 4,000 Pacific Western Aboriginals are harboring HTLV-I genome. The total full blooded native population in B.C. is $74,420 .{ }^{24}$ This suggests a seroprevalence of $5.4 \%$ and a prevalence of $5.4 / 100,000$ for HAM/TSP. We have not attempted to recognize all B.C. cases and foresee reaching 
Table 2. Probable Routes of Infection and Essential Results of Patients and Husband/Wife

\begin{tabular}{|c|c|c|c|c|c|c|}
\hline & $\mathrm{BT}^{1}$ & IVDA $^{2}$ & Sex & Vertical & ELISA I/II ${ }^{3}$ & $\mathbf{P C R}^{4}$ \\
\hline $\mathrm{Ham}^{1}$ & + & - & - & - & + & + \\
\hline Healthy hsb Ham' & - & - & + & - & + & + \\
\hline $\mathrm{Ham}^{2}$ & - & - & + & - & + & + \\
\hline Healthy hsb Ham² & + & + & + & - & + & + \\
\hline $\mathrm{Ham}^{3}$ & - & - & - & + & + & + \\
\hline Healthy hsb Ham ${ }^{3}$ & - & - & + & - & + & + \\
\hline $\mathrm{Ham}^{4}$ & + & + & + & - & + & + \\
\hline Healthy hsb Ham ${ }^{4}$ & - & - & + & - & - & ND \\
\hline ATLL $^{1}$ & - & + & + & - & + & ND \\
\hline Healthy Wife & + & - & + & - & + & + \\
\hline
\end{tabular}

'BT = Blood transfusion

${ }^{2}$ IVDA = Intravenous drug abuse

${ }^{3}$ Screening ELISA against HTLV-I and HTLV-II

${ }^{4}$ Viral DNA rescued by HTLV-I specific PCR amplification

the figure of $12 / 100,000$ reported for Jamaica as a whole; in Jamaica HAM/TSP can rise to $100 / 100,000$ in some socio economic subgroups.' Japanese studies have also revealed that the lower the frequency of infection in the population the higher the chances that HAM be acquired by blood transfusion. ${ }^{25}$ In nonendemic Japanese prefectures the percentage of HAM acquired by blood transfusion was $38 \%$ versus $21 \%$ in endemic prefectures. Two of our 4 patients (Patient \#1 and Patient \#4) have received a blood transfusion 30 years and 4 years previously. In Patient \#2 it is the husband who received a blood transfusion.

Our figures are small but suggest low endemicity of HTLV-I in the Aboriginal population of B.C. This is an important fact for Neurologists to consider in the evaluation of neurological disorders and especially multiple sclerosis in Natives. It could be necessary that public health measures be taken to limit the spreading of the infection. ${ }^{26}$ In the absence of such measures, the patients reported here and their families could be the basis for higher levels of HTLV-I contamination in Canada.

\section{Aknowledgemen'1}

We thank the neurologists of B.C. who referred these patients to us especially Dr. J. Beckman, Dr. V. Makin, and Dr. D.W. Paty. We are indebted to the family physicians who have helped us gather the clinical samples Drs. S. Shah, D. Kirk and M. Abbey (Port Hardy), Dr. J. Pocock (Gold River), Dr. H. Garson (Campbell River). Dr. L.D. McDonald (Port Alberni). We thank Drs. J.M. Connors and R. Gascoyne at BCCA, and the staff at Provincial Laboratory at B.C. Centre for Disease Control who all helped in facilitating the investigation of the cases and family members. Elaine King is thankfully acknowledged for her technical assistance and Anne Schaffar for her secretarial skill. G.A.D. is a career scientist from the Ontario Ministry of Health. Funds used for this research were partially provided by the MRC of Canada and Christopher Investments LId. (Vancouver).

\section{REFERENCES}

I. Romàn GC. The neuroepidemioplogy of Tropical spatic paraparesis Ann Neurol 1988; 23 (Suppl): S113-S120.

2. Osame M, Matsamuto M, Usuka K, et al. Chronic progressive myelopathy associated with elevated antibodies to HTLV-I and adult T-cell leukemia-like cells. Ann Neurol 1987; 21: 117-122.

3. Vernant J-C, Maurs L, Gout O, et al. HTLV-1 associated tropical spastic paraparesis in Martinique: a reappraisal. Ann Neurol 1988; 23 (Suppl): S133-S135.

4. Gessain A, Barin F, Vernant JC, et al. Antibodies to human T-lymphotrophic virus type 1 in patients with tropical spastic paraparesis. Lancet 1985; ii: 407-410.
5. McKendall RR, Oas J, Lairmore MD. HTLV-1 associated myelopathy endemic in Texas-born residents and isolation of virus from CSF cells. Neurology 1991; 41: 831-836.

6. Power C, Weinshenker BG, Dekaban GA, et al. HTLV-I associated myelopathy in Canada. Can J Neurol Sci 1989; 16: 330-335.

7. Dekaban G, Werker D, Foti D, et al. HTLV-I infection associated with disease in three aboriginal indian families from British Columbia: a serological and PCR analysis: Submitted.

8. Gessain A, Barin F, Vernant JC, et al. Antibodies to human T-lymphotropic virus type-1 in patients with tropical spastic paraparesis. Lancet $1985 ; 2: 407-410$.

9. Iwasaki Y. Human T cell leukemia virus type I infection and chronic myelopathy. Brain Pathology 1993; 3: 1-10.

10. Jacobson S, Gupta A, Mattson D, Mingioli E, McFarlin DE Immunological studies in tropical spastic paraparesis. Ann Neurol 1990; 27: 149-156.

11. McKendall RR, Oas J, Lairmore MD. HTLV-1 associated myelopalthy endemic in Texas-born residents and isolation of virus from CSF cells. Neurology 1991; 41: 831-836.

12. Osame M, Janssen R, Kubota $H$, et al. Nationwide survey of HTLV-1-associated myelopathy in Japan: association with blood transfusion. Ann Neurol 1990; 28: 50-56.

13. Williams AE, Fang CE, Slamon DJ, et al. Seroprevalence and epidemiological correlates of HTLV-1 infection in U.S. blood donors. Science 1988; 240: 643-646.

14. Sheremata W, DeFreitas E, Sazant A. TSP in the United States: a study of Florida cases and relationship to multiple sclerosis. I $n$ : Romàn GC, Vernant JC, Osama M, eds. HTLV-I and the nervous system. New York: Alan Liss, 1989; 185-192.

15. Sadovnick AD, Ebers GC. Epidemiology of multiple sclerosis: a critical overview. Can J Neurol Sci 1993; 20: 17-29.

16. Dekaban GA, Hudson AJ, Rice GPA. Absence of HTLV-I and HTLV-II proviral genome in the brains of patients with multiple sclerosis and amyotrophic lateral sclerosis. Can J Neurol Sci 1992; 19: 458-461.

17. Poser C, Paty D, Scheinberg L, et al. New diagnostic criteria for multiple sclerosis. Ann Neurol 1983; 13: 227-231.

18. Schumacher GA, Beebe RF, Kibler R, et al. Problems in experimental trials of therapy in multiple sclerosis: report by the panel of evaluation of experimental trials of therapy in multiple sclerosis. Ann NY Acad Sci 1965; 122: 522-568.

19. Kajiwama W, Kashiwagi S, Ikematsu H, et al. Intrafamilial transmission of adult $T$ cell leukemia virus. J Infect Dis 1986; 154 : 851-857.

20. Manns A, Blattner WA. The epidemiology of the human T-cell lymphotrophic virus type 1 and type II. Transfusion 1991; 31: 67-75.

21. Salazar-Grueso EF, Holzer TJ, Gutierrez RA, et al. Familial spastic paraparesis syndrome associated with HTLV-l infection. New England J Med 1990; 323: 732-737.

22. Dekaban GA, Inwood M, Waters D, Droulin J, Teitel J. Absence of HTLV-I/II in an Ontario hemophillia population, Canada. Transfusion. In Press. 
23. Khabbaz RF, Onorato IM, Cannon RO, et al. Seroprevalence of HTLV-I and HTLV-II among intravenous drug users and persons in clinics for sexually transmitted diseases. N Engl J Med 1992; 326: 375-380.

24. Statistics Canada: Number of natives in British Columbia answering to a single ancestry and stating they are natives. Data from Canada 1991 census.
25. Poser $\mathrm{CM}$, Romàn GC, Vernant J-C. Multiple sclerosis or HTLV-1 myelitis? Neurology 1990; 40: 1020-1022.

26. CDC and USPHS Working group: guidelines for counseling persons infected with HTLV-I and HTLV-II Ann Int Med 1993; 118: 448-454. 